\title{
International Security Threat in 21st Century
}

\author{
Jia Ximing ${ }^{1 *}$, Shao Yuteng ${ }^{2}$, You $\mathrm{Qi}^{3}, \mathrm{He}$ Dingyi $^{4}$, Wu Zhiyuan ${ }^{5}$ \\ ${ }^{1}$ School of Politics and Public Administration, Tianjin Normal University, Tianjin 300380, China \\ ${ }^{2}$ Fuzhou No.3 Middle school, Fujian, Fuzhou 350001, China \\ ${ }^{3}$ San Diego State University, San Diego, California, 92182, U.S \\ ${ }^{4}$ Maple Leaf International School-Wuhan, Wuhan, Hubei 430074, China \\ ${ }^{5}$ Balwyn High School, Balwyn North, Victoria, 3104, Australia \\ *Corresponding author: jiaxim@163.com
}

\begin{abstract}
In the new era, international relations have reached the peak of complexity, followed by a variety of international threats. This paper identifies two dominant international threats of the contemporary world, the detrimental void of international leadership and the terrorism with the possible solution. Furthermore, the essay demonstrates the connections between these threats with the strong evidence and analysis of specific issue.
\end{abstract}

Keywords: Dominant international threats; International leadership; Terrorism

\section{INTRODUCTION}

International relations and international security have become a more popular topic among scholars and researchers. Recent years have demonstrated turbulence and quick changes in the international community caused by various elements, such as the void international leadership and the continuing battle against rising terrorism.

In this research, debate regarding potential threats to the current international system is organized into two main sections. The first section analyzes the void international leadership, including the decline of competency in U.S. leadership in the current order and the capability of China which is still insufficient to replace the United States. The second section talks about how terrorism poses a more immediate threat to international security than other elements. Lastly, the essay argues that there is a close relationship between these two major threats of international security.

\section{THE VOID OF INTERNATIONAL LEADERSHIP}

\subsection{The decline of American hegemony caused by American discontinued foreign policy}

The American discontinued foreign policy is the biggest threat to international security. The withdrawal of the United States from international organizations and the imposition of huge military defense charges on its Allies to finance the deficit has shaken the legitimacy of the American hegemony system. Mr. Trump's further revival of the domestic economy will further weaken the "dollar hegemony". The worst result is that the United States damaged the international system which maintaining its vested interests as well as disrupt the international economic order. The arrival of the financial crisis intensified misunderstanding between countries and insecurity of the countries, which may eventually lead to war.

\subsubsection{American hegemony}

Since the end of the Second World War, the United States has built a hegemony system by being deeply engaged in the international affairs. The Washington Consensus has given legitimacy to American hegemony. As the regulation maker, the United States used international institutions and regulations to maintain its vested advantage and deeply embedded the liberalism, which is advocated by the United States, in the international system. At the same time, as the leader of the international order, the United States keeps providing "free" international public goods for the international order, offering security guarantees to its freeloading allies and promoting open economic exchange. What's more, though the U.S. hegemony formed an order for maintain its own advantage in getting international profit, it also creates a formidable economic and strategic rival. ${ }^{[1]}$

Compared with the Trump era, the United States before the Trump era has a clearly articulated sense of purpose and agency that the United States wants to remain its role like the beacon of liberal democracy as well as maintain the benefits and advantages offered by the existing American hegemony international system. 


\subsubsection{The discontinued foreign policy}

American discontinued foreign policy mainly reflects in its withdrawal from multilateral institutions and aiming to reduce security bills by pushing its Allies to pay more. For Trump's senior economic adviser, the world is an area for international participation to compete instead of a "global community", which relies on hegemon to provide benevolent service. Trump seems to prefer a cost-benefit bilateralism, he believes America gets a raw deal from the liberal international order and one-on-one deals is cheaper for America than underwriting globalized multilateralism. ${ }^{[2]}$ President Trump promises to 'make America great again' by playing hardball with allies, overturning the LIO if necessary. ${ }^{[3]}$ Under the lead of Trump, the United States seldom acts moderately but negotiates more aggressively with other nations, threaten to leave international agreements and alliances if necessary. Since election Trump as U.S. president, the United States leaves several international organizations, such as TPP, the Paris Agreement on climate change, United Nations Educational, Scientific and Cultural Organization. Moreover, the United States is eager to ask its Allies to increase their military spending and the number the United States asking is too big for its Allies to support. In sum, Trump's leading and the new foreign policy the United States is implementing are eroding the sources of American hegemony power by destroying its institutional infrastructure and legitimacy.

\subsubsection{The threat to international security brought by the absence of American leadership}

There is irreconcilable conflict between the "dollar hegemony" and the American domestic interest. Considering American total debt and the Trump's determination to revive the domestic economy, the essay argues that the United States doesn't have the capability to bear the higher security bills, lower commercial benefits and greater monetary burdens all by itself. Trump's discontinued foreign policy is eroding the "dollar hegemony" and bringing risks to the international financial system which may cause a worldwide financial crisis. As the result, look back into the past, may break the temporary peace in the international security.

Trump's discontinued foreign policy is sharping the primacy of American military. But American military hegemony is playing a positive role in maintaining "dollar hegemony". In other words, Trump's discontinued foreign policy is indirectly shaking the foundation of "dollar hegemony", bringing more hardships to collective security system and its symbiotic economic security system. The United States support for the LIO in the form of liberal hegemony and deep engagement has aimed to promote the twin goals of security and prosperity by building security alliances and an economic order rooted in strong institutions and liberal values. ${ }^{[3]}$ In May 2020, the Treasury department of the United States post that the American total debt is 25 trillion dollars. ${ }^{[4]}$ It is not irrational for Trump to withdraw from a costly American hegemony system. But the American hegemony system is a wholeness, including ideologic hegemony, "dollar hegemony" and military hegemony. The American military primacy has positive retroaction on "dollar hegemony", while the "dollar hegemony" also can easily shift economic risks for the Unite States and provide a stable source of funding for its military development. American global security regimes have allowed the United States to structure regional international relations and other states' international economic preferences in ways it considers conducive to its interests. ${ }^{[2]}$ In Sum, the economic and military hegemony are interdependent. Nowadays, Trump seems to refuse to give a free-ride chance to its allies, which never happened before. If its allies can't accept American expensive military protecting bill and stop cooperating with the United States, the situation for both the United States and its allies will be hard to handle.

Trump's discontinued foreign policy is shaking the foundation of "dollar hegemony" by acting like a normal country which works hard on reducing its trade deficits. Trump's focus on reviving the domestic economy is undermining the value and role of the American dollar. As the world's currency, the decline of the American dollar will lead to an economic crisis and may trigger the world war. As the Triffin dilemma described, using the U.S. dollar as the global currency requires the United States to provide extra cash to other countries through trade deficits. On the other hand, keeping long-term current account deficits will raise concerns about the U.S. capability of paying back the debt, which will cause the depreciation of American dollars and threaten its role as the global currency. In order to maintain its role as a global currency, the U.S. dollar must not depreciate significantly, which requires the U.S. to keep the current account balance. ${ }^{[5]}$ In sum, the "dollar hegemony" and the goal of reducing American trade deficits cannot be achieved at the same time. Since the election of Donald J. Trump as U.S. president in November 2016, the foreign economic policy is discontinued. Under Trumps' lead, the United State decreasing the sponsorship fee of international institutions, advocating bilateralism and emphasize absolute interests in international trade. To some extent, it has reduced the role of the dollar on the international stage. What's more, the United States responses to domestic economic risks by printing dollars and shifting the risks to other countries cause the depreciation of American dollars. At the international level, domestic political and economic problems in the United States have seriously damaged the credibility and attractiveness of the Washington consensus. $^{[2]}$

What's more, America's discontinued foreign policy is confusing other nations. It is quite possible that other nations will fall into insecurity and take risky military actions for assuming that the United States will rule the world militarily and rob their money. 


\subsection{China's Inability to Replace US as a Leader}

Contrasting to common beliefs, China is unlikely to replace US to become the world leader because of its own limitations. Firstly, even though China has risen economically, it does not rise politically. It lacks control of international organizations, which will obstacle China's position as a leader. For example, although it has the right of veto in the UN, which symbolizes its high status in the organization, it cannot use the UN to project its influence towards other countries as the organization is still widely controlled by US and its allies, which means China's attempt to exercise its power can be easily terminated. Not only the UN, but also most of the international organizations, such as the Permanent court of Arbitration, World Trade Organization and World Health Organization are currently or previously dominated by the US. In 2016, China lost the tribunal of the arbitration of the South China Sea. Despite its refusal of the case, it still demonstrates China's inability to manipulate the organization like what the US did. The liberal international order heavily relies on these international organization to act as a tool for the leader to moderate and resolve problems. Without controlling them, a state cannot be an adequate leader. Furthermore, it fails to provide other countries a sense of security. Unlike the US, which is able to maintain a long term friendly with its neighbors and its allies, China is constantly having disputes with nearly all its neighbors like Japan and Vietnam, mostly because of territories. This dispute is likely to cause fear among other countries and they could overreact to some of China's policies, which will prevent China from being an effective leader.

Secondly, even though China's economy has risen significantly, it is not yet strong enough to become the world leader. Its currency is not internationally used, which means it cannot establish a dollar hegemony like the US to help it mitigate the damage from economic crisis. Moreover, China's economy largely relies on trading with other states. According to WTO statistics, in 2019 17\% of China's GDP comes from exporting. If other countries' economy starts recessing, they will be buying products from China less, and China's economy will also be impacted. China also imports plenty of resources. China is currently the largest importer of crude oil, with an import rate of 10.1 million barrels per day (see Figure 1 for details) ${ }^{[15]} \mathrm{A}$ rise of oil price can largely increase the cost of production, and hurt its economy. With such a vulnerable economy, China cannot take the cost of becoming the world leader.

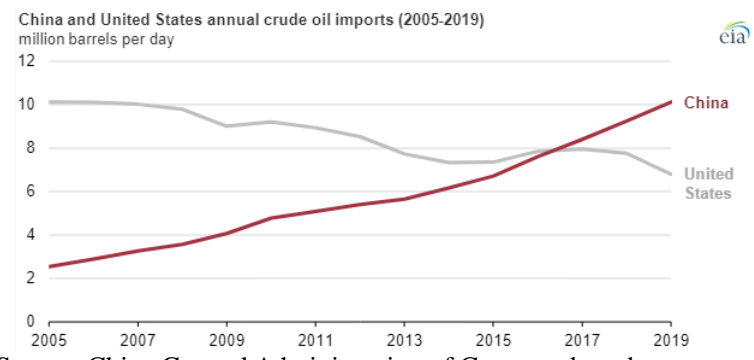

Source: China General Administration of Customs, based on Bloomberg, L.P.

Figure 1 China and United States annual crude oil imports (2005-2019)

Lastly, China's relatively weak military strength does not allow it to take over the leadership. It does not have the ability to project its military power around the world like US. However, this ability is the most needed one to become the world leader. Without it, China can neither provide assistance to its allies nor maintain order for a safe environment in regions other than East Asia. To illustrate, China is unable to protect its companies in Africa and India, but US can protect its profit around the world, including Europe, Asia and the Middle East because of its military bases around the world that allows it to project its military power.

In conclusion, all the limitations do not allow China to become the world leader. The liberal international order still requires the United States to maintain. However, the United States is prioritizing its own benefit. The economic and military hegemony are interdependent. The withdrawal of the United States from international organizations and the imposition of huge military defense charges on its Allies to finance the deficit have shaken the legitimacy of the American hegemony system and confused other countries, especially the Allies of the United States. When those countries feel insecure, they will take risks and wars are more likely to happen. With the development of science and technology, attackers will not be easy to detected as before, and misunderstandings between countries may eventually lead to the outbreak of global war.

\section{TERRORISM}

\subsection{What is terrorism?}

For decades, despite the visible threat of military competition or the rise of other nations, an unpredictable and phantom signal is threatening the global order and bringing the fire and terror to the place it reaches, terrorism However, the misconception and the stereotype of terrorism is significant nowadays, which generate the fear of unknown. There is a common misunderstanding about the terrorism is that the innocent civilian is always the target of terrorism to maltreat. In fact, the tactics of targeting civilian is ubiquitous, which is not precise enough to show the essence of terrorism. ${ }^{[6]}$ 
To be more specific, terrorism is a violence waged by organization or campaigns with strategy in order to gain rational goal. Either the goal of coercing their target for the reason of politics or religion, or they regard terrorism as a medium to create widespread influence or gain supporters. Hamas, for instance, is a Palestinian Sunni-Islamic fundamentalist militant organization, which stemmed from the ingrained Palestinian Israeli conflict, This terrorism rebel group had launch many attacks on Jewish group and intifadas. In fact, the action of Hamas is the representative of fanatics and irrationality. ${ }^{[7]}$ Even so their intrinsic goal is generally to coerce the Israel government and to obtain enough territory space with the need to break the sanction for decades, which is shown in the incidence of the withdrawal of Israeli troops in West bank and Gaza. ${ }^{[7]}$

The two outstanding goals of terrorism are intended to pursue at the same time in majority of the cases. As the essays mentioned above, Hamas aims to liberate Palestine from Israeli occupation by resisting it, the supporters of rebellion are necessary to provide the incentive to legitimate the terrorists' act in their side. Thanks to the explanation of Islamic Jihad, Hamas is successful to lighten the hatred of the mainstream of Palestinian with terrorism.

Additionally, Terrorism is a weapon to signal weakness rather than strength. When we consider the problem of terrorism, it is important to comprehend the essence of the act. It is a war for weakness to against the strong. First, the feature of terrorism is attacking civilian as a grave signal instead of the direct confrontation of the military force of the target government. In fact, the achievement of a successful signal is difficult. As Virginia Page Fortna mentioned, "To be credible, signal has to be costly, precisely because it is less costly to attack soft civilian target than harden military ones. Terrorism signals impotence rather than strength. ${ }^{[6] "}$ Besides, the weakness of terrorism is creating a coercive leverage, because of the strength gap. The attacks on the target government would, to some extent, convince their citizens that their government is vulnerable to the future raid. The feeling of insecurity would be beneficial to balance the concept of power between two groups.

\subsection{Why is it the important threat in the world?}

There are many factors that make the terrorism become the most important threat in the world. Here I list 2 main reasons and cite some specific cases to explain it.

\subsubsection{Terrorism makes long-run uncertainty}

In $21^{\text {st }}$ century, terrorism is the most important threat to the contemporary world there will be less possibility for the "hot war" between the countries, and this leads the international society to pay more attention on terrorism. In this case, the military force will be dispatched to the place where the terrorism is prevalent, and this would bring the regional instability. For example, after U.S. invade Iraq in order for "counter-terrorism", the Iraq was struggle in war and turmoil for next several years. In another hand, just like what the words mentioned in section 1 , it leads to a long-run effect for the society or nations and still has the influence today. The international society and each nation should consider about how to tackle the threat from terrorism at any time.

Finally, as the different aspects of society (e.g technology, cities, etc.) are developing, the society will become weaker and more vulnerable to face such threat - the terrorists will always update their strategies so that the nations have to pay much more efforts and modify the policy frequently to solve it.

\subsection{2. $\quad$ Terrorism is unpredictable}

U.S. intelligence agencies were failed to trace the foreign terrorists before the 911 attack. ${ }^{[8]}$ An example shown is Al-Mihdhar, one hijacker during the 9.11 attack. His personal information is collected by CIA, but after the attack George Tenet, the Director of Central Intelligence acknowledge that the State Department should put al-Mihdhar into the watch list and refuse him to enter the U.S. This fact exposes lack of ability to trace the foreign terrorists of U.S. intelligence agencies.

However, the U.S. intelligence agencies are lack of ability to trace the foreign terrorists. One reason the U.S. intelligence agencies are lack of ability is bureaucracy. Bureaucracy increases the internal complexity of U.S. intelligence community and that's why the U.S intelligence communities cannot function effectively. Besides, Self-interest causes legislators not desire to modify such intricate intelligence agencies like president because it will not bring direct benefits to the people who vote for them so that they might lose the support. ${ }^{[8]}$

Another reason for lack of ability to trace the foreign terrorists is different agencies are lack of cooperation between each other and not able to share the information efficiently. In this case, the intelligence agencies will not obtain the latest or the most accurate information. This would lead to the lethal result like 9.11 attack.

In the long run, the intelligence agencies will not be able to catch the pace of change in external environment. First, as the cities, or we can say urban area, developed rapidly, terrorists will desire to innovate their strategies to establish an attack. ${ }^{[9]}$ Again, just like the 9.11 attack or attack in Kunming Railway station in 2014, terrorists will prefer to target the place in the city where has the high population density (e.g. Skyscrapers, bus depots, and railway stations) and that will could be lethal and lead to lots of casualty. Furthermore, it is easier for terrorists to get the weapon or material to establish an attack. For example, the FLN in Algeria usually utilize the bombing in urban area where they can get the plastic explosives. ${ }^{[9]}$

By the way, the development of technology also provides the opportunities for terrorists to set up an attack. The 
advanced technology on communication and transportation network are beneficial for terrorists to expand their operation further so that they can attack in different regions. ("publicity" and "mobility"). ${ }^{[9]}$ For example, Terrorists prefer to hijack the aircrafts to get the recognition from international society to achieve their political purposes. Indeed, such operations were first existed in 1930s. ${ }^{[10]}$ In the past time, this could be a low-cost but high reward activity for terrorists since sometimes the government does not want to see the serious result that it will give terrorists an amount of money and nothing damaged or even no one hurt in this process. Now there is still high risk of terrorism for aviation though in recent times the collaboration between nations become closer. One of the most obvious examples is people still need to experience the strict security check before boarding.

\subsection{Global issue analysis}

There is no doubt that the terrorism is a global issue that pose a great threat on the international security order. Admittedly, the origins of traditional terrorism are concentrated on the Middle East. Even though, since advanced democratic countries interfere their affair through military actions and occupation, the modern transnational terrorism attacks have come into being. From my perspective, it is a grave influence on democratic society. Since 2001, the United State controversial intervention of the Afghanistan War give rise to the Al Qaeda's retaliation on September 11th. ISIS also show their anger and hatreds to the France government in Paris on November 2015, which is the greatest French crisis for centuries, which offer terrorism the sufficient reasons why. Secondly, the democracy in general has the vulnerable feature which is fragile when it is comes to the raid of terrorism. Liberal democracy particularly, is possess with the freedom of speeches, protest of rally, and the open and free media. It is very convenient for to accommodate the needs of terrorism; the barriers of provocation and recruitment is scant. Additionally, one of the significant features of democracy is the observing human rights, to some extent, the risk of terrorism is relatively low. As Paul Wilkinson said in his book: "There is always the risk that using heavy repression to crush the terrorism campaign the authorities may alienate the innocent majority of citizens caught up in the procedures of house-to-house searches and interrogations. ${ }^{[11]}$,

With the well-developed internet, it is terrorism that spread internationally. Terrorism groups found a new way to spread the propaganda and ideology. According to the data, YouTube boasting more than 1 billion users each month. This break down into 6 million hours of video that are been watched each month and $100 \mathrm{~h}$ of video are uploaded to YouTube each month. ${ }^{[12]}$ On average 350,000 are been sent per minute and 500 million tweets on twitter per day. ${ }^{[13]}$ The utilization of cyber-terrorism is prevalent nowadays. One has to pay attention to the dominant users of all these social media, the youth. It offers the terrorist group such as Isis to take the advantages of this feature.
They can manipulate individual grievance and dissatisfaction render those vulnerable to feel more significant. ${ }^{[14]}$ Besides, it is plausible to polish the image of themselves and render young people to think it is cool to fight with them.

\subsection{How to tackle the terrorism?}

The solution of terrorism has always been a profound problem, due to its complex essence. For decades, countries are trying to bring their military superiority in to full play, the peace keeping process of bombing seems to be the effective method of eliminate the terrorism. However, military sanction may cure the symptoms, but not the diseases. The indiscriminate bombing is possible to hurt enormous civilians, bombardment to destroy their homeland, eventually, they may turn to terrorism groups solely for being bullied by the so-called peace-making process. In fact, we always have the antidote and alternatives.

\subsubsection{International efforts}

Although the government should reinforce the security domestically or adopt the military operation overseas after terrorism activity happens, the most effective way is to solve it politically.

To promote the international society to collaborate on strike terrorism. Different countries have variety of standard on recognizing terrorism, so that it is hard to strike effectively. Only if the countries achieve the consensus on define the terrorism and work together, the terrorism can be solved essentially.

Another way to solve the terrorism is negotiation. To be honest, negotiation is a good way to promote the cooperation between the countries, but it also can help to solve the conflict between government and terrorism organization. With using the method of negotiation, the government will directly know or infer out what are the goals of terrorism organizations and then the government can decide the next strategy they use for counterterrorism.

\subsubsection{Domestic efforts: Enhance Domestic security}

After the 911 attacks, The Congress of the United States passed the Patriot Act one month later on October 26, 2001.It has made comprehensive laws for anti-terrorism and safeguarding the security of the United States. China, for instance, in line with the international community's counter-terrorism initiatives Strengthen the management of explosives and other dangerous goods, and strengthen the management of entry-exit and border control. Strictly prevent terrorists from entering or leaving the country illegally 
Terrorism is always an act, but not a certain race, when we protect our country from been attacked by the terrorist as a citizen in our daily life. One shall never fall in the trap of racism. Instead we shall respect Muslim, Middle east, and people with the ideology different from you. Overall, they are partially the victim of terrorism.

\section{CONCLUSION}

In conclusion, the essay argues that there is a close relationship between the two major threats of international security. Trump's discontinued foreign policy is increasing the cost of its Allies security which may lead to more possibilities for each country to develop its own military power and the terrorism may have a broader space for development. There is no doubt that the terrorism is a global issue with long-term uncertainty and intuitive casualties that needs to be solved essentially by achieving consensus on defining the terrorism and cooperation among all the subjects of international relations. But the void international leadership will make the cooperation for international security lack effective leading and stable source of funding, which indicates the prevention of terrorism in the perspective of democracy and social media would be almost dysfunctional.

To end with, the essay provides a referable solution which is to let all countries be involved in the existing international order and shoulder some of their "obligations" instead of getting free-ride. The capacity of the United States is weakening and that of China is still insufficient so this is the moment when the world should come together to make up for the void single leadership. Although the United States is less able to maintain world hegemony on its own, the international order is still under the American hegemony. The United States should open the door of LIO to the countries which have different ideology, at the same time, the rising countries should do some effort to make the shifting of international order safe and moderate.

\section{REFERENCES}

[1] Beeson, Mark, and Nathan Watson. "Is International Leadership Changing Hands or Disappearing? China and the USA in Comparative Perspective." Asian Perspective 43, no. 2 (2019): 387-415. https://doi.org/10.1353/apr.2019.0015.

[2] Stokes, Doug. "Trump, American Hegemony and the Future of the Liberal International Order." International Affairs 94, no. 1 (January 2018): 133-50. https://doi.org/10.1093/ia/iix238.
[3] Norrlof, Carla. "Hegemony and Inequality: Trump and the Liberal Playbook." International Affairs 94, no. 1 (January 2018): 63-88. https://doi.org/10.1093/ia/iix262.

[4] "REPORTS." Government - The Debt to the Penny and Who Holds It. Accessed May 14, 2020. https://www.treasurydirect.gov/govt/reports/pd/pd_debttot hepenny.htm.

[5] Sheng, Liugang, Hongyan Zhao, and Jing Zhao. "Why Will Trump Lose the Trade War?" China Economic Journal 12, no. 2 (2019): 137-59. https://doi.org/10.1080/17538963.2019.1603634.

[6] Virginia Page Fortna (2015). Do Terrorists Win? Rebels' Use of terrorism and Civil War Outcomes.International organization, 69 p522.

[7] Robert. A.Pape (2003)The Strategic Logic of Suicide Terrorism, American Political Science Review. 97, No.4, p352

[8] Amy B. Zegart, "September 11 and the Adaptation Failure of U.S. Intelligence Agencies", International Security, Vol. 29, No. 4 (Spring 2005), pp. 78-111.

[9] Martha Crenshaw, "The Causes of Terrorism," Comparative Politics, Vol. 13, No. 4 (July 1981), pp. 379-399.

[10] Jonah Fisher, "The man who carried out one of the world's earliest hijackings", BBC News, June 2014.

[11] Paul Wilkinson. Terrorism Versus Democracy: The liberal state response ( third edition), 2016. London and New York: Routledge 22.

[12] YouTube Statistics 2014. Viewership. Accessed 20 Dec 2014.Available https://www.youtube.com/yt/press/en-GB/statistics.html

[13] Witter 2014. Usage Statistics. Available at: http://www.internetlivestats. com/twitter-statistics/.

[14] Awan, I., \& Blakemore, B. 2012. Policing cyber hate, cyber threats, and cyber terrorism. London: Ashgate Publishing.

[15] "U.S. Energy Information Administration - EIA Independent Statistics and Analysis." China's crude oil imports surpassed 10 million barrels per day in 2019 Today in Energy - U.S. Energy Information Administration (EIA). Accessed July 18, 2020. https://www.eia.gov/todayinenergy/detail.php?id=43216 